\title{
Pemilihan food outlet sebagai faktor risiko berat badan lebih anak usia sekolah dasar di Kecamatan Tegalsari Surabaya
}

\author{
Food outlet choice as a risk factor of overweight/ obesity status at elementary school in Tegalsari \\ Disctrict Surabaya
}

Renny Evelyn Hartono ${ }^{1}$, BJ. Istiti Kandarina², Siti Helmyati²

\begin{abstract}
Introduction: Overweight and obesity are conditions resulting from an imbalance of calories in the body that occur in a long time and cause more deaths than underweight. One of factor s related is food pattern, which also influenced the selection of food outlets. Surabaya is an urban area so it has many types and characteristic s of food outlet. Elementary school $(4,5,6)$ do not really depend on their parents, so their food consumption and physical activity began to vary.

Objective: To identify the relationship between the selection of food outlets and overweight/obesity status of elementary school in Tegalsari district, Surabaya.

Methods: This research used a case-control study design. Samples were 51 children for each group of cases and control and obtained from 11 primary school in the 5 subdistrict s in Tegalsari district, Surabaya. Data were obtained by interview, direct observation of food outlets, and interview to select informants about the reasons of selecting food outlets. Quantitative data were processed by bivariate (chi-square) and multivariate (binomial regression) test.

Results: Bivariate test results showed that there were significant relationships between the frequency to the street vendors consumption (OR=4.09, 95\% Cl:1.60-10.75), frequency of fast food consumption (OR=2.86, 95\% Cl:1.19-6.94) and snacks (OR=6,05, 95\% Cl:2.20-17.62), physical activity (OR=3.09, 95\% $\mathrm{Cl}: 1.28-7.51)$ and gender (OR=2.70, 95\% Cl:1.11-6.64) with overweight/obesity status, while frequency of stores (total, supermarket, market, mini-market), frequency of food service place (total, restaurants, fast food restaurants), frequency of vegetable and fruit consumption, and socio-economic status of respondents did not relate significantly. In multivariate analysis, the variables that affected frequency of the street vendors were snack consumption, physical activity, sex and total expenditure.

Conclusions: Frequency of the street vendors, fast food consumption, physical activity,gender, and total expenditure had relationship with overweight/obesity status.
\end{abstract}

KEYWORDS: food outlet, obesity, overweight

\begin{abstract}
ABSTRAK
Latar belakang: Overweight dan obesitas adalah keadaan akibat ketidakseimbangan kalori dalam tubuh yang terjadi dalam waktu lama dan menjadi penyebab kematian lebih banyak dibanding underweight. Salah satu faktor yang berhubungan langsung adalah pola makan, yang juga dipengaruhi pemilihan food outlet. Surabaya merupakan daerah perkotaan sehingga memiliki jenis dan karakteristik food oulet lebih beragam. Anak usia SD kelas IV, V, VI sudah tidak terlalu bergantung pada orang tua, sehingga konsumsi pangan dan aktivitas fisiknya mulai beragam.

Tujuan: Mengetahui hubungan antara pemilihan food outlet dan status berat badan lebih pada anak usia sekolah dasar di Kecamatan Tegalsari, Surabaya.
\end{abstract}

\footnotetext{
${ }^{1}$ Pasca Sarjana IImu Kesehatan Masyarakat Minat Gizi dan Kesehatan, Fakultas Kedokteran, Universitas Gadjah Mada, Jl. Farmako Sekip Utara, e-mail: renny@ratson.com

${ }^{2}$ Program Studi Gizi dan Kesehatan, Fakultas Kedokteran Universitas Gadjah Mada, Jl. Farmako Sekip Utara, Yogyakarta 55281
} 


\begin{abstract}
Metode: Penelitian menggunakan desain studi kasus-kontrol. Sampel penelitian adalah 51 anak untuk masing-masing kelompok kasus dan kontrol dari 11 SD di 5 Kelurahan di Kecamatan Tegalsari, Surabaya. Data diperoleh dengan wawancara, observasi langsung ke food outlet dan wawancara alasan pemilihan food outlet pada informan terpilih. Data kuantitatif diolah dengan uji bivariat (chi-square) dan multivariariat (regresi binomial).

Hasil: Uji bivariat menyatakan terdapat hubungan signifikan antara frekuensi datang ke pedagang kaki lima $(O R=4,09,95 \% \mathrm{Cl}: 1,60-10,75)$, frekuensi konsumsi fast food (OR=2,86, 95\% Cl:1,19-6,94) dan kudapan $(O R=6,05,95 \% \mathrm{Cl}: 2,20-17,62)$, aktivitas fisik (OR=3,09, 95\% Cl:1,28-7,51) serta jenis kelamin (OR=2,70, 95\% Cl:1,11-6,64) dengan berat badan lebih, sedangkan frekuensi ke food store (total, supermarket, pasar, mini-market), frekuensi ke food service place total, rumah makan, restoran fast food), pola konsumsi sayur buah, dan sosial ekonomi responden tidak berhubungan signifikan. Pada analisis multivariat, variabel yang mempengaruhi frekuensi datang ke pedagang kaki lima adalah frekuensi konsumsi kudapan, aktivitas fisik, jenis kelamin, dan total pengeluaran.

Kesimpulan: Frekuensi datang ke pedagang kaki lima, konsumsi kudapan, aktivitas fisik, jenis kelamin, dan total pengeluaran berhubungan dengan status berat badan lebih.
\end{abstract}

KATA KUNCI: food outlet, overweight, obesitas

\section{PENDAHULUAN}

Kegemukan meningkat tidak hanya di negara-negara maju, tetapi juga di negaranegara berkembang, seperti Indonesia, dan telah menyebabkan kematian lebih banyak dibanding underweight (1). Berdasarkan data riset kesehatan dasar (Riskesdas) tahun 2010 (2), prevalensi obesitas berdasarkan indek massa tubuh menurut umur (IMT/U) nasional adalah 9,2\% dan prevalensi di Provinsi Jawa Timur telah melebihi prevalensi nasional, yaitu sebesar $12,4 \%$. Melihat hal ini, maka permasalahan kegemukan pada anak usia sekolah dasar perlu mendapat perhatian karena obesitas pada masa anak-anak memiliki kecenderungan untuk menjadi obesitas pada masa dewasa. Sekitar 42-63\% anak penderita obesitas usia sekolah dasar tetap mengalami obesitas pada saat dewasa (3).

Obesitas merupakan hasil interaksi dari beberapa hal. Salah satu faktor langsung yang berpengaruh adalah konsumsi pangan dan aktivitas fisik, sementara satu faktor tidak langsung adalah pemilihan food outlet. Food outlet memiliki karakteristik masing-masing sehingga akan mempengaruhi konsumsi pangan seseorang. Food outlet dapat dikelompokkan menjadi dua kelompok besar: food stores (supermarket, mini-market dan pasar tradisional) dan food service places (rumah makan, restoran fast food dan pedagang kali lima). Beberapa penelitian terdahulu telah membuktikan bahwa food outlet memiliki pengaruh terhadap kejadian obesitas, seperti keberadaan supermarket yang memiliki efek penurunan IMT dan keberadaan mini market serta restoran fast food yang meningkatkan IMT $(4,5)$.

Penelitian food outlet selalu dihubungkan dengan IMT serta kejadian overweight/obesitas dan bukan kejadian kekurusan/underweight karena individu yang overweight/obesitas memiliki variasi pola konsumsi dan asupan pangan lebih beragam. Melihat beberapa fakta tersebut, maka perlu dilakukan penelitian lebih lanjut untuk melihat hubungan antara pemilihan food outlet dan kejadian berat badan lebih pada anak usia sekolah dasar di Kecamatan Tegalsari, Surabaya yang terletak di Surabaya pusat, sehingga memiliki food outlet dalam jumlah cukup banyak dengan jenis dan karakteristik yang lebih beragam. Pemilihan food outlet diduga memiliki hubungan dengan status berat badan lebih pada anak usia sekolah dasar, khususnya kelas IV, V, dan VI yang aktivitas fisik dan konsumsi pangannya mulai beragam.

\section{BAHAN DAN METODE}

Penelitian ini menggunakan desain studi kasus-kontrol dan dilakukan di Kecamatan Tegalsari, Surabaya selama bulan Februari hingga Mei 2014. Studi ini membandingkan 51 anak dengan berat 
badan lebih (IMT/U $\geq+1 \mathrm{SD}$ ) untuk kelompok kasus dan 51 anak dengan berat badan normal (-2 SD < IMT/U < +1 SD) untuk kelompok kontrol. Sampel diperoleh dari 11 SD di 5 kelurahan di Kecamatan Tegalsari, yaitu SD Karitas I Surabaya, SD Khadijah Pandegiling, SDN Dr. Sutomo VIII/330, SDN Kedungdoro V/310, SDN Kedungdoro VI/311, SD Santa Maria Surabaya, SDN Keputran III/334, SDS Serba Guna Surabaya, SDN Tegalsari II/322, SD Mardi Sunu Surabaya, dan SDN Wonorejo VI/317. Kriteria inklusi adalah anak sekolah dasar (kelas IV, $\mathrm{V}$, dan VI) dan mendapat izin tertulis dari orang tua, sedangkan kriteria eksklusi adalah menjalani diet khusus dan menderita penyakit kronik.

Variabel terikat dari penelitian ini adalah status gizi, dengan variabel bebas pemilihan food outlet. Variabel luar yaitu: pola konsumsi pangan, aktivitas fisik, dan riwayat obesitas ayah/ibu. Variabel pengganggu yaitu: jenis kelamin, jumlah saudara, pekerjaan ayah/ibu, pendidikan ayah/ibu, pengeluaran, dan kepemilikan mobil. Pemilihan food outlet dibagi menjadi food store (frekuensi ke supermarket, pasar, mini-market, dan total frekuensi) dan food service place (frekuensi ke rumah makan, restoran fast food, pedagang kaki lima, dan total frekuensi) dan pola konsumsi pangan dilihat dari frekuensi konsumsi sayur buah, fast food dan kudapan.

Data diperoleh dengan melakukan wawancara kepada 102 responden menggunakan kuesioner yang telah diujikan kepada 20 orang, observasi langsung ke food outlet (lokasi, ketersediaan, harga) menggunakan form yang telah disesuaikan dari beberapa penelitian terdahulu $(6,7)$. Data yang telah diperoleh dikategorikan dengan mengadopsi penelitian sebelumnya $(8,9,10,11,12,13,14,15)$ serta wawancara kepada 20 orang tua responden terpilih menggunakan panduan wawancara yang telah diujicobakan pada 10 orang.

Data yang diperoleh selanjutnya dianalisis menggunakan analisis univariat, bivariat, dan multivariat (uji regresi binomial dan uji MantelHaenszel). Penelitian ini telah mendapatkan surat kelaikan etik/ethical clearance dengan nomor: Ref/ KE/FK/183/EC tahun 2014.

\section{HASIL}

Data karakteristik dan sosial-ekonomi responden dapat dilihat pada Tabel 1. Kelompok kasus dan kontrol memiliki karakteristik hampir sama, hanya berbeda pada jenis kelamin. Anak lakilaki 2,7 kali lebih berisiko untuk mengalami berat badan lebih dibanding anak perempuan $(\mathrm{OR}=2,70$, 95\% Cl:0,11-6,64).

Data pemilihan food outlet, pola konsumsi pangan, dan aktivitas fisik dapat dilihat pada Tabel 2. Sebagian besar responden memiliki frekuensi ke supermarket 1 kali/bulan dan frekuensi ke pasar 5-7 kali/minggu. Frekuensi konsumsi sayur dan buah pada anak sebagian besar dikategorikan jarang. Anak yang sering mengonsumsi fast food dan kudapan lebih berisiko mengalami berat badan lebih sebanyak 2,86 (OR=2,86, 95\% Cl:0,17-1,83) dan 6,05 (OR=6,05, 95\% Cl:2,20-17,62) kali lebih besar. Jenis makanan yang dikonsumsi responden dapat dilihat pada Tabel 3. Pemilihan food outlet yang berhubungan dengan status berat badan lebih adalah frekuensi ke pedagang kaki lima dengan frekuensi yang sering akan meningkatkan risiko berat badan lebih sebanyak 4,09 kali (OR=4,09, 95\% Cl:1,60-10,75).

Aktivitas fisik anak pada kelompok kasus lebih banyak yang tergolong rendah, sedangkan pada kelompok kontrol lebih banyak yang tergolong sedang, tetapi nilai rata-rata MET-menit/minggu pada kelompok kasus $(884,7 \pm 747,7)$ lebih tinggi dibandingkan kelompok kontrol $(849,5 \pm 172,5)$ karena perbedaan jenis atau intensitas aktivitas fisik yang dilakukan.

Sebagian besar anak tidak tidur siang karena memiliki jam masuk sekolah siang. Rata-rata durasi tidur anak adalah $8,79 \pm 1,37$ jam (kasus) dan 9,11 $\pm 1,03$ jam (kontrol), sedangkan rata-rata durasi menonton TV adalah 2,01 $\pm 0,65$ jam (kasus) dan 1,93 $\pm 0,86$ jam (kontrol), dan rata-rata durasi main games adalah $0,84 \pm 0,93$ jam (kasus) dan $0,80 \pm 0,93$ (kontrol).

Data ketersediaan food outlet hasil observasi langsung adalah supermarket yang memiliki skor health food availability index (HFAl) tertinggi yaitu 86 dari total skor 96 , dengan rincian 39 
Tabel 1. Karakteristik dan sosial ekonomi responden

\begin{tabular}{|c|c|c|c|c|c|c|c|}
\hline \multirow[t]{2}{*}{ Variabel } & \multicolumn{2}{|c|}{$\begin{array}{l}\text { BB Lebih } \\
\text { (kasus) }\end{array}$} & \multicolumn{2}{|c|}{$\begin{array}{c}\text { Normal } \\
\text { (kontrol) }\end{array}$} & \multirow[t]{2}{*}{$\mathbf{p}$} & \multirow[t]{2}{*}{ OR } & \multirow[t]{2}{*}{$95 \% \mathrm{Cl}$} \\
\hline & $\mathbf{n}$ & $\%$ & $\mathbf{n}$ & $\%$ & & & \\
\hline \multicolumn{8}{|l|}{ Jenis kelamin } \\
\hline Laki-laki & 27 & 26,47 & 15 & 14,71 & $0,02^{*}$ & 2,70 & $1,11-6,64$ \\
\hline Perempuan & 24 & 23,53 & 36 & 35,29 & & & \\
\hline \multicolumn{8}{|l|}{ Jumlah saudara } \\
\hline Sedikit $(\leq 3$ orang) & 50 & 49,02 & 48 & 47,06 & 0,31 & 3,13 & $0,24-167,25$ \\
\hline Banyak (> 3 orang) & 1 & 0,98 & 3 & 2,94 & & & \\
\hline \multicolumn{8}{|l|}{ Pendidikan ayah } \\
\hline Rendah (SD/SMP/SMA sederajat) & 35 & 34,31 & 29 & 28,43 & 0,22 & 1,66 & $0,68-4,05$ \\
\hline Tinggi (S-I, S-II atau lebih) & 16 & 15,69 & 22 & 21,57 & & & \\
\hline \multicolumn{8}{|l|}{ Pendidikan ibu } \\
\hline Rendah & 38 & 37,25 & 36 & 35,29 & 0,66 & 1,22 & $0,47-3,21$ \\
\hline Tinggi & 13 & 12,75 & 15 & 14,71 & & & \\
\hline \multicolumn{8}{|l|}{ Pekerjaan ayah } \\
\hline Non-swasta & 12 & 11,76 & 9 & 8,82 & 0,46 & 1,44 & $0,49-4,31$ \\
\hline Swasta & 39 & 38,24 & 42 & 41,18 & & & \\
\hline \multicolumn{8}{|l|}{ Pekerjaan ibu } \\
\hline Bekerja & 15 & 14,71 & 19 & 18,63 & 0,40 & 0,70 & $0,28-1,74$ \\
\hline Tidak bekerja & 36 & 35,29 & 32 & 31,37 & & & \\
\hline \multicolumn{8}{|l|}{ Kepemilikan mobil } \\
\hline Punya & 18 & 17,65 & 19 & 18,63 & 0,84 & 0,92 & $0,38-2,23$ \\
\hline Tidak punya & 33 & 32,35 & 32 & 31,37 & & & \\
\hline \multicolumn{8}{|l|}{ Pengeluaran } \\
\hline Tinggi ( $\geq$ median) & 28 & 27,45 & 23 & 22,55 & 0,32 & 1,48 & $0,63-3,48$ \\
\hline Rendah (< median) & 23 & 22,55 & 28 & 27,45 & & & \\
\hline \multicolumn{8}{|l|}{ Riwayat obesitas ayah } \\
\hline Obesitas & 10 & 9,80 & 9 & 8,82 & 0,80 & 1,14 & $0,37-3,52$ \\
\hline Tidak obesitas & 41 & 40,20 & 42 & 41,18 & & & \\
\hline \multicolumn{8}{|l|}{ Riwayat obesitas ibu } \\
\hline Obesitas & 13 & 12,75 & 8 & 7,84 & 0,22 & 1,83 & $0,62-5,68$ \\
\hline Tidak obesitas & 38 & 37,25 & 43 & 42,16 & & & \\
\hline
\end{tabular}

* Signifikan $(p<0,05)$

skor kesehatan dari total skor 49 dan skor penuh senilai 47 untuk ketersediaan. Setelah supermarket, pasar menempati urutan kedua dengan total skor 50 (22 skor kesehatan, 28 skor ketersediaan), dan pada urutan terakhir adalah minimarket dengan total skor 37 (12 skor kesehatan, 25 skor ketersediaan).

Secara keseluruhan, bahan pangan yang lebih sehat (rendah lemak, tanpa pengawet, dan lain-lain) memiliki harga yang lebih tinggi daripada bahan pangan reguler. Supermarket memiliki harga bahan pangan kemasan sedikit lebih murah dibanding minimarket, tetapi memiliki harga bahan pangan segar (sayur, buah, daging, ikan) lebih tinggi dibandingkan dengan pasar.

Berdasarkan hasil analisis multivariat, model akhir yang dipilih adalah model 3. Pada model 3 terdapat lima variabel yang memiliki nilai $p<0,05$, yaitu frekuensi ke pedagang kaki lima, frekuensi konsumsi kudapan, aktivitas fisik, jenis kelamin, dan pengeluaran. Pada ketiga model sebelumnya, nilai $p$ untuk kelima variabel tersebut juga signifikan $(p<0,05)$, namun pemilihan model 3 didasarkan pada nilai bayesian information criteria (BIC) yang lebih rendah. Nilai BIC yang lebih rendah menunjukkan bahwa persamaan atau model tersebut lebih baik (uji goodness of fit) (Tabel 4).

Berdasarkan hasil analisis bivariat, pengeluaran memiliki nilai $p>0,25$ (Tabel 1), namun demikian dalam analisis multivariat memiliki nilai $p<0,05$. Hal ini menandakan bahwa pengeluaran merupakan variabel confounding dari hubungan frekuensi ke pedagang kaki lima dengan berat badan lebih. Hal ini dipertegas 
Tabel 2. Pemilihan food outlet responden

\begin{tabular}{|c|c|c|c|c|c|c|c|}
\hline \multirow{2}{*}{ Variabel } & \multicolumn{2}{|c|}{ BB lebih (kasus) } & \multicolumn{2}{|c|}{ Normal (kontrol) } & \multirow{2}{*}{$\mathbf{p}$} & \multirow{2}{*}{ OR } & \multirow{2}{*}{$95 \% \mathrm{Cl}$} \\
\hline & $\mathbf{N}$ & $\%$ & $\mathbf{N}$ & $\%$ & & & \\
\hline \multicolumn{8}{|l|}{ Food store } \\
\hline Jarang ( $<5$ kali/ minggu) & 10 & 9,80 & 11 & 10,78 & 0,8066 & 0,89 & $0,30-2,59$ \\
\hline Sering ( $\geq 5 \mathrm{kali} / \mathrm{ming}$ u) & 41 & 40,20 & 40 & 39,22 & & & \\
\hline \multicolumn{8}{|l|}{ Supermarket } \\
\hline Jarang ( $<1$ kali/ minggu) & 35 & 34,31 & 32 & 31,37 & 0,5315 & 1,30 & $0,53-3,20$ \\
\hline Sering ( $\geq 1 \mathrm{kali} /$ minggu) & 16 & 15,69 & 19 & 18,63 & & & \\
\hline \multicolumn{8}{|l|}{ Pasar } \\
\hline Jarang ( $<3$ kali/ minggu) & 13 & 12,75 & 14 & 13,73 & 0,8224 & 0,90 & $0,34-2,39$ \\
\hline Sering ( $\geq 3 \mathrm{kali} / \mathrm{minggu}$ ) & 38 & 37,25 & 37 & 36,27 & & & \\
\hline \multicolumn{8}{|l|}{ Minimarket } \\
\hline Sering ( $\geq 1 \mathrm{kali} /$ minggu) & 35 & 34,31 & 32 & 31,37 & 0,5315 & 1,30 & $0,53-3,20$ \\
\hline Jarang (< $1 \mathrm{kali} /$ minggu) & 16 & 15,69 & 19 & 18,63 & & & \\
\hline \multicolumn{8}{|l|}{ Food servive place } \\
\hline Sering $(\geq 6 \mathrm{kali} / \mathrm{ming} g \mathrm{u})$ & 30 & 29,41 & 25 & 24,51 & 0,3206 & 1,49 & $0,63-3,50$ \\
\hline Jarang (<6 kali/ minggu) & 21 & 20,59 & 26 & 25,49 & & & \\
\hline \multicolumn{8}{|l|}{ Rumah makan } \\
\hline Sering ( $\geq 1 \mathrm{kali} /$ minggu $)$ & 24 & 23,53 & 22 & 21,57 & 0,6906 & 1,17 & $0,50-2,75$ \\
\hline Jarang (<1 kali/ minggu) & 27 & 26,47 & 29 & 28,43 & & & \\
\hline \multicolumn{8}{|l|}{ Restoran fast food } \\
\hline Sering ( $\geq 1$ kali/ minggu) & 12 & 11,76 & 15 & 14,71 & 0,5008 & 0,74 & $0,28-1,95$ \\
\hline Jarang (<1 kali/ minggu) & 39 & 38,24 & 36 & 35,29 & & & \\
\hline \multicolumn{8}{|l|}{ Pedagang kaki lima } \\
\hline Sering ( $\geq 4$ kali/ minggu) & 40 & 39,22 & 24 & 23,53 & $0,0011^{*}$ & 4,09 & $1,60-10,75$ \\
\hline Jarang (< 4 kali/ minggu) & 11 & 10,78 & 27 & 26,47 & & & \\
\hline \multicolumn{8}{|l|}{ Frekuensi konsumsi sayur dan buah } \\
\hline Jarang ( $\leq 4$ kali/ minggu) & 40 & 39,22 & 44 & 43,14 & 0,2988 & 0,58 & $0,17-1,83$ \\
\hline Sering (> 4 kali/ minggu) & 11 & 10,78 & 7 & 6,86 & & & \\
\hline \multicolumn{8}{|l|}{ Frekuensi konsumsi fast food } \\
\hline Sering ( $\geq 1 \mathrm{kali} /$ minggu) & 30 & 29,41 & 17 & 16,67 & $0,0098^{*}$ & 2,86 & $1,19-6,94$ \\
\hline Jarang ( $<1$ kali/ minggu) & 21 & 20,59 & 34 & 33,33 & & & \\
\hline \multicolumn{8}{|l|}{ Frekuensi konsumsi kudapan( } \\
\hline Sering ( $\geq 3$ kali/ hari) & 27 & 26,47 & 8 & 7,84 & $0,0001^{*}$ & 6,05 & $2,20-17,62$ \\
\hline Jarang (<3 kali/ hari) & 24 & 23,53 & 43 & 42,16 & & & \\
\hline \multicolumn{8}{|l|}{ Aktivitas fisik } \\
\hline $\begin{array}{l}\text { Rendah (<600 metabolic equivalent } \\
\text { (MET)-menit/ minggu) }\end{array}$ & 33 & 32,35 & 19 & 18,63 & & & \\
\hline Sedang ( $\geq 600 \mathrm{MET}$-menit/ minggu) & 18 & 17,65 & 32 & 31,37 & $0,0056^{*}$ & 3,09 & $1,28-7,51$ \\
\hline Tinggi ( $\geq 3000$ MET-menit/ minggu) & 0 & 0,00 & 0 & 0,00 & & & \\
\hline
\end{tabular}

* Signifikan $(p<0,05)$

Tabel 3. Jenis konsumsi pangan responden

\begin{tabular}{cccc}
\hline Sayur & Buah & Fast food & Kudapan \\
\hline Wortel & Pepaya & Ayam goreng & Keripik \\
Kubis & Pisang & Kentang goreng & Chiki \\
Buncis & Semangka & Minuman bersoda & Biskuit \\
Tomat & Apel & & Donat \\
Sawi hijau & Jeruk & & Gorengan \\
Bayam & Mangga & & Mie instan \\
Kangkung & Rambutan & & Teh manis \\
Kacang panjang & Jambu biji (jus) & & Es degan \\
& Alpukat (jus) & & Es krim \\
& & Susu \\
& & Soto \\
& & & Bakso \\
\hline
\end{tabular}


Tabel 4. Analisis multivariat faktor-faktor yang berhubungan dengan berat badan lebih

\begin{tabular}{|c|c|c|c|}
\hline Variabel & $\begin{array}{c}\text { Model } 1 \\
\text { OR } \\
(95 \% \mathrm{Cl}) \\
\mathrm{p}\end{array}$ & $\begin{array}{c}\text { Model } 2 \\
\text { OR } \\
(95 \% \mathrm{Cl}) \\
\text { p }\end{array}$ & $\begin{array}{c}\text { Model } 3 \\
\text { OR } \\
(95 \% \mathrm{Cl}) \\
\text { p }\end{array}$ \\
\hline $\begin{array}{l}\text { Pedagang kaki lima } \\
\text { Sering } \\
\text { Jarang }\end{array}$ & $\begin{array}{c}12,16 \\
(2,63-56,19) \\
0,001^{*}\end{array}$ & $\begin{array}{c}7,25 \\
(1,86-28,26) \\
0,004^{*}\end{array}$ & $\begin{array}{c}7,41 \\
(2,15-25,56) \\
0,002^{*}\end{array}$ \\
\hline $\begin{array}{l}\text { Frekuensi kudapan } \\
\text { Jarang } \\
\text { Sering }\end{array}$ & $\begin{array}{c}7,08 \\
(1,52-33,06) \\
0,013^{*}\end{array}$ & $\begin{array}{c}5,17 \\
(1,3-20,54) \\
0,020^{*}\end{array}$ & $\begin{array}{c}6,37 \\
(1,79-22,61) \\
0,004^{*}\end{array}$ \\
\hline $\begin{array}{l}\text { Frekuensi fast food } \\
\text { Jarang } \\
\text { Sering }\end{array}$ & $\begin{array}{c}4,29 \\
(1,08-16,98) \\
0,038^{*}\end{array}$ & $\begin{array}{c}3,07 \\
(0,98-9,60) \\
0,054\end{array}$ & \\
\hline $\begin{array}{l}\text { Aktivitas fisik } \\
\text { Sedang } \\
\text { Tinggi }\end{array}$ & $\begin{array}{c}15,19 \\
(3,52-65-60) \\
0,000^{*}\end{array}$ & $\begin{array}{c}10,70 \\
(2,94-38,95) \\
0,000^{*}\end{array}$ & $\begin{array}{c}5,59 \\
(1,88-16,64) \\
0,002^{*}\end{array}$ \\
\hline $\begin{array}{l}\text { Jenis kelamin } \\
\text { Perempuan } \\
\text { Laki-laki }\end{array}$ & $\begin{array}{c}6,23 \\
(1,52-25,56) \\
0,011^{*}\end{array}$ & $\begin{array}{c}4,69 \\
(1,37-16,04) \\
0,014^{*}\end{array}$ & $\begin{array}{c}2,93 \\
(1,03-8,38) \\
0,045^{*}\end{array}$ \\
\hline $\begin{array}{l}\text { Total pengeluaran } \\
\text { Rendah } \\
\text { Tinggi }\end{array}$ & $\begin{array}{c}10,48 \\
(1,74-63,02) \\
0,010^{*}\end{array}$ & $\begin{array}{c}11,89 \\
(2,63-53,86) \\
0,001^{*}\end{array}$ & $\begin{array}{c}5,90 \\
(1,69-20,60) \\
0,005^{*}\end{array}$ \\
\hline $\begin{array}{l}\text { Jumlah saudara } \\
\text { Sedikit } \\
\text { Banyak }\end{array}$ & $\begin{array}{c}20,96 \\
(0,97-453,70) \\
0,052\end{array}$ & $\begin{array}{c}15,52 \\
(0,97-249,28) \\
0,053\end{array}$ & \\
\hline $\begin{array}{l}\text { Pendidikan ayah } \\
\text { Rendah } \\
\text { Tinggi }\end{array}$ & $\begin{array}{c}4,07 \\
(0,69-24,04) \\
0,121\end{array}$ & $\begin{array}{c}1,74 \\
(0,49-6,15) \\
0,393\end{array}$ & \\
\hline $\begin{array}{l}\text { Pekerjaan ayah } \\
\text { Non-swasta } \\
\text { Swasta }\end{array}$ & $\begin{array}{c}1,38 \\
(0,34-6,41) \\
0,649\end{array}$ & & \\
\hline $\begin{array}{l}\text { Riwayat obesitas ayah } \\
\text { Tidak obesitas } \\
\text { Obesitas }\end{array}$ & $\begin{array}{c}1,56 \\
(0,38-6,41) \\
0,536\end{array}$ & & \\
\hline $\begin{array}{l}\text { Pendidikan ibu } \\
\text { Rendah } \\
\text { Tinggi }\end{array}$ & $\begin{array}{c}0,28 \\
(0,07-1,12) \\
0,192\end{array}$ & & \\
\hline $\begin{array}{l}\text { Pekerjaan ibu } \\
\text { Tidak bekerja } \\
\text { Bekerja }\end{array}$ & $\begin{array}{c}3,83 \\
(0,82-17,91) \\
0,071\end{array}$ & & \\
\hline $\begin{array}{l}\text { Riwayat obesitas ibu } \\
\text { Tidak obesitas } \\
\text { Obesitas }\end{array}$ & $\begin{array}{c}3,83 \\
(0,82-17,91) \\
0,088\end{array}$ & $\begin{array}{c}2,94 \\
(0,73-11,91) \\
0,13\end{array}$ & \\
\hline $\begin{array}{l}\text { Kepemilikan mobil } \\
\text { Tidak punya } \\
\text { Punya }\end{array}$ & $\begin{array}{c}2,90 \\
(46-18,19) \\
0257\end{array}$ & & \\
\hline $\mathrm{BIC}$ & $-321,1710$ & $-338,3479$ & $-346,7872$ \\
\hline
\end{tabular}

* Signifikan $(p<0,05)$

dengan hasil analisis stratifikasi atau uji MantelHaenszel. Selisih nilai crude OR dan $\mathrm{OR}_{\mathrm{M}-\mathrm{H}}$ lebih besar dari $20 \%$. Selisih nilai crude OR dan $\mathrm{OR}_{\mathrm{M}-\mathrm{H}}$ yang lebih besar dari $20 \%$ menunjukkan bahwa variabel stratifikasi tersebut merupakan variabel confounding dari hubungan variabel bebas dan variabel terikat (Tabel 5).

\section{BAHASAN}

Hubungan pemilihan food outlet dengan berat badan lebih

Hasil penelitian menunjukkan frekuensi ke food store tidak berhubungan signifikan dengan berat badan lebih (Tabel 2) karena sebagian 
Tabel 5. Analisis stratifikasi berdasarkan pengeluaran

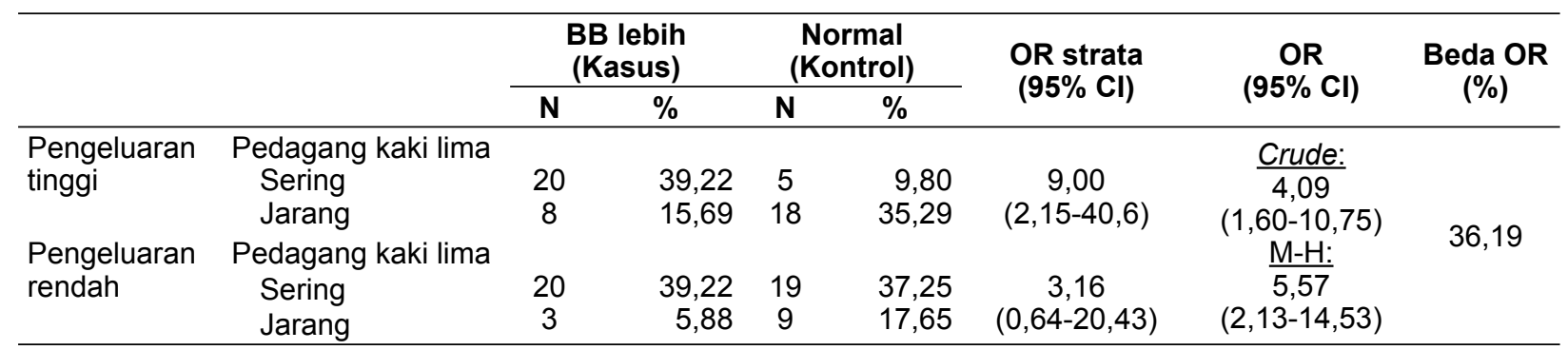

besar responden jarang ke supermarket dan lebih sering ke pasar. Supermarket merupakan pilihan belanja bulanan karena memiliki kualitas lebih baik, ketersediaan lebih lengkap (16), dan harga bahan pangan kemasan lebih murah (17), sedangkan pasar menjadi tempat utama untuk membeli kebutuhan pangan sehari-hari karena lebih dekat dan harga bahan pangan segar lebih murah dengan kualitas tidak jauh berbeda dari supermarket. Minimarket menjadi tempat tujuan untuk kebutuhan mendadak dan bila terdapat harga diskon.

Dari ketiga jenis food outlet, yang memiliki hubungan signifikan dengan berat badan lebih hanya pedagang kaki lima, karena sebagian besar responden memiliki ekonomi menengah ke bawah (Tabel 2). Individu dengan ekonomi rendah akan lebih sering ke pedagang kaki lima karena lebih murah dan lebih jarang ke rumah makan dan restoran fast food. Hal ini dibuktikan dengan hasil analisis stratifikasi, dengan selisih nilai crude OR dan $\mathrm{OR}_{\mathrm{M}-\mathrm{H}}$ lebih besar dari 20\% (36,19\%) (Tabel 5). Dengan kata lain, pengeluaran merupakan variabel confounding dari hubungan frekuensi ke pedagang kaki lima dengan berat badan lebih.

Orang tua lebih memilih memasak sendiri untuk makanan utama karena nilai kebersihan dan nilai gizi lebih terjamin, serta lebih dapat memenuhi selera keluarga. Frekuensi ke pedagang kaki lima yang sering berhubungan dengan konsumsi kudapan anak saat di sekolah dan waktu senggang di rumah.

Hasil wawancara menunjukkan bahwa alasan orang tua responden memiliki frekuensi sering ke food service place adalah karena kurangnya waktu untuk memasak sendiri. Orang tua tersebut bekerja dan memang sengaja untuk makan di luar rumah sebagai variasi bersamaan rekreasi keluarga.

\section{Hubungan pola konsumsi pangan dengan berat badan lebih}

Hasil menunjukkan frekuensi konsumsi sayur dan buah tidak berhubungan signifikan dengan berat badan lebih (Tabel 2), karena hampir seluruh anak jarang mengonsumsi sayur dan buah. Konsumsi sayur anak dipengaruhi preferensi rasa yang juga dipengaruhi pengenalan tekstur dan rasa saat kecil, ketersediaan di rumah, model yang dapat diikuti, dan preferensi yang diturunkan (18). Individu dengan frekuensi dan jumlah konsumsi sayur dan buah yang lebih banyak memiliki nilai IMT lebih rendah (18) karena sayur dan buah memiliki densitas energi rendah dan kandungan serat tinggi (19). Hasil penelitian Nuraeni et al. tahun 2013 di Kota Yogyakarta dan Kabupaten Bantul juga membuktikan bahwa anak kelas 1-5 SD yang jarang dan sedikit mengonsumsi buah dan sayur berisiko menjadi obes (20).

Hasil uji bivariat menunjukkan bahwa anak yang sering mengonsumsi fast food lebih berisiko 2,86 kali untuk berat badan lebih karena konsumsi fast food memiliki porsi besar, densitas energi dan total lemak tinggi (21-23), serta meningkatkan konsumsi minuman bersoda, dan menurunkan konsumsi sayur dan buah (24). Namun demikian, pada analisis multivariat tidak menunjukkan hubungan signifikan karena ketika bersamaan dengan faktor lain, faktor-faktor tersebut memiliki hubungan lebih kuat dengan berat badan lebih dan pada penelitian ini hanya melihat frekuensi konsumsi saja tanpa melihat kuantitas (Tabel 4).

Frekuensi kudapan yang sering mengakibatkan anak lebih berisiko untuk berat badan lebih 4,85 kali, karena kudapan memiliki densitas energi, kandungan gula dan garam dan proporsi energi dari lemak yang tinggi (25). 


\section{Hubungan aktivitas fisik dan berat badan lebih}

Hasil penelitian ini menunjukkan anak dengan aktivitas fisik rendah lebih berisiko 3,09 kali untuk berat badan lebih (Tabel 2). Aktivitas fisik dapat menurunkan risiko berat badan lebih karena merupakan kegiatan penyumbang pengeluaran energi terbesar (20-50\% dari total pengeluaran) $(26,27)$. Untuk mencapai manfaat bagi kesehatan, aktivitas fisik yang dilakukan minimal memiliki intensitas sedang, dan aktivitas berat akan memberikan manfaat yang lebih baik (28). Anak pada kelompok kasus memiliki rata-rata METmenit/minggu lebih besar $(884,7)$ dibanding pada kelompok kontrol $(747,7)$ yang berarti berat badan lebih pada kelompok kasus, ada yang disebabkan memiliki aktivitas fisik rendah dan ada pula yang disebabkan oleh terbentuknya massa otot akibat memiliki aktivitas fisik intensitas tinggi.

Aktivitas fisik dalam intensitas rendah seperti menonton televisi, main games, dan durasi tidur juga berhubungan dengan berat badan lebih. Menonton televisi dan main games lebih berhubungan dengan asupan kalori dari snack yang dikonsumsi selama menonton, efek paparan iklan pangan di televisi, dan berkurangnya waktu aktivitas fisik $(29,30)$. Durasi tidur memiliki hubungan " $U$-shape" dengan berat badan lebih dengan nilai IMT minimum diperoleh pada ratarata durasi tidur 7-8 jam setiap malam (31). Waktu tidur yang kurang juga dapat menyebabkan kelelahan dan rasa kantuk sepanjang hari serta mengurangi waktu untuk aktivitas fisik (16).

\section{Hubungan karakteristik dan sosial ekonomi dengan berat badan lebih}

Anak laki-laki memiliki risiko berat badan lebih besar daripada perempuan karena memiliki frekuensi kudapan lebih sering (Tabel 1). Anak laki-laki lebih banyak mengonsumsi minuman bersoda (32), makanan berlemak dan manis, daging, produk olahan daging dan telur (33), sehingga memiliki rata-rata asupan energi yang lebih tinggi $(24,15)$. Karakteristik lain seperti jumlah saudara, pendidikan dan pekerjaan orang tua, riwayat obesitas orang tua dan kepemilikan mobil tidak berhubungan signifikan dengan berat badan lebih karena kurangnya variasi karakteristik dari responden. Jumlah saudara lebih banyak menurunkan risiko berat badan lebih (34) karena interaksi antaranak meningkat (35) dan distribusi makanan setiap individu semakin sedikit (36). Pendidikan formal dan pekerjaan dari orang tua tidak selalu sebanding dengan pengetahuan dan sikap yang baik. Kepemilikan mobil juga tidak terlalu berpengaruh karena frekuensi ke food service place dan supermarket dari responden tidak terlalu sering.

Pengeluaran pada analisis bivariat tidak berhubungan signifikan karena sebagian besar responden memiliki ekonomi menengah ke bawah (Tabel 1), yaitu persentase pengeluaran pangan lebih besar dari data Bappeda Jatim tahun 2012. Namun pada analisis multivariat menunjukkan hubungan signifikan (Tabel 4). Pengeluaran tinggi lebih berisiko untuk berat badan lebih. Individu dengan ekonomi yang baik lebih sering mengonsumsi pangan di luar rumah yang berhubungan dengan konsumsi total energi, densitas energi, kandungan lemak, gula, dan garam yang tinggi serta nilai gizi yang rendah $(37,38)$.

\section{KESIMPULAN DAN SARAN}

Tidak terdapat hubungan antara pemilihan food stores (frekuensi ke food stores, supermarket, pasar, dan mini market) dan status berat badan lebih pada anak usia sekolah dasar di Kecamatan Tegalsari, Surabaya. Namun demikian, food stores yang memiliki kecenderungan menyebabkan berat badan lebih adalah supermarket dan mini-market.

Pemilihan food service places yang berhubungan dengan status berat badan lebih hanya pedagang kaki lima, sedangkan food service places lainnya (frekuensi ke food service places, rumah makan dan restoran fast food) tidak berhubungan dengan status berat badan lebih pada anak usia sekolah dasar di Kecamatan Tegalsari, Surabaya.

Saran dalam penelitian yaitu sebaiknya diberikan edukasi kepada anak-anak tentang kualitas dan kuantitas makanan yang sehat, terutama kudapan yang banyak dikonsumsi anak-anak. Memberikan edukasi kepada penjaja makanan tentang jajanan pangan atau kudapan yang sehat dan menyajikan pilihan makanan dan kudapan yang sehat pada kantin sekolah juga penting dilakukan. 


\section{RUJUKAN}

1. WHO (World Health Organization). Obesity and overweight [Internet]. [cited 2013 Nov 11]. Available from: http://www.who.int/mediacentre/ factsheets/fs311/en/

2. Balitbangkes (Badan Penelitian dan Pengembangan Kesehatan) KKR. Riset kesehatan dasar (Riskesdas) 2010 [Internet]. 2010 [cited 2014 Jun 16]. Available from: http://surabayakota.bps.go.id/index. php?hal=tabel\&id=4

3. Serdula M, Ivery D, Coates R, Freedman D, Williamson D, Byers T. Do obese children become obese adults? a review of the literature. Prev Med (Baltim). 1993;22(2):167-77.

4. Morland K, Diez Roux A V., Wing S. Supermarkets, other food stores, and obesity: the atherosclerosis risk in communities study. Am J Prev Med. 2006;30(4):333-9.

5. Inagami S, Cohen DA, Brown AF, Asch SM. Body mass index, neighborhood fast food and restaurant concentration, and car ownership. J Urban Heal. 2009;86(5):683-95.

6. Allen D, Filice J, Patel N, Warner B. Analyzing food security in Worcester. Worcester: Faculty of Worcester Polytechnic Institute; 2012.

7. Moreno-Black G, Johnson-Shelton D, Boles S. Bethel scholl district report: grocery store food environment. Eugene; 2013.

8. Mushtaq MU, Gull S, Shahid U, Shafique MM, Abdullah HM, Shad MA, et al. Family-based factors associated with overweight and obesity among Pakistani primary school children. BMC Pediatr [Internet]. 2011;11:114-22. Available from: http:// www.biomedcentral.com/1471-2431/11/114

9. Monteiro C, Conde W, Popkin B. Independent effects of income and education on the risk Brazilian adult population. J Nutr. 2001;(131):881S - 886S.

10. Lear $S$ a, Gasevic D, Schuurman N. Association of supermarket characteristics with the body mass index of their shoppers. Nutr J [Internet]. 2013;12:117-24. Available from: http://www. pubmedcentral.nih.gov/articlerender.fcgi?artid $=3751149 \&$ tool $=$ pmcentrez\& $\&$ rendertype $=a b s t r$ act
11. Fulkerson JA, Farbakhsh K, Lytle L, Hearst MO, Dengel DR, Pasch KE, et al. Away-fromhome family dinner sources and associations with weight status, body composition, and related biomarkers of chronic disease among adolescents and their parents. J Am Diet Assoc. 2011;111(12):1892-7.

12. Mushtaq MU, Gull S, Mushtaq K, Shahid U, Shad MA, Akram J. Dietary behaviors, physical activity and sedentary lifestyle associated with overweight and obesity, and their socio-demographic correlates, among Pakistani primary school children. Int J Behav Nutr Phys Act [Internet]. 2011;8(1):130-42. Available from: http://www. pubmedcentral.nih.gov/articlerender.fcgi?artid $=3$ 250930\&tool=pmcentrez\&rendertype $=$ abstract

13. Sartika R. Faktor risiko obesitas pada anak 5-15 tahun di Indonesia. Makara Kesehat. 2011;15(1):37-43.

14. Aini S. Faktor risiko yang berhubungan dengan kejadian gizi lebih pada remaja di perkotaan. Unnes J Public Heal. 2012;1(2):1-8.

15. IPAQ (International Physical Activity Questionnaire). Guidelines for data processing and analysis of the International Physical Activity Questionnaire (IPAQ) - short and long forms [Internet]. 2005. Available from: 10 Juni 2014

16. Vilaro MJ, Barnett TE. The rural food environment: a survey of food price, availability, and quality in a rural Florida community. Food Public Heal. 2013;3(3):111-8.

17. Short a., Guthman J, Raskin S. Food deserts, oases, or mirages?: small markets and community food security in the San Francisco bay area. J Plan Educ Res. 2007;26(3):352-64.

18. Vanhala ML, Laitinen J, Kaikkonen K, Kein??nenKiukaanniemi S, Korpelainen R. Parental predictors of fruit and vegetable consumption in treatment-seeking overweight children. J Hum Nutr Diet. 2011;24:47-53.

19. Ledoux TA, Hingle MD, Baranowski T. Relationship of fruit and vegetable intake with adiposity: a systematic review. Obes Rev. 2011;12(5):e143-50.

20. Nuraeni I, Hadi H, Paratmanitya Y. Perbedaan konsumsi buah dan sayur pada anak sekolah 
dasar yang obes dan tidak obes di Kota Yogyakarta dan Kabupaten Bantul. J Giz dan Diet Indones. 2013; 1(2): 81-92.

21. Mair J, Pierce M, Teret S. The use of zoning to restrict fast food outlets: a potential strategy to combat strategy [Internet]. Journal The Center for Law and the Public's Health at Johns Hopkins \& Georgetown Universities. 2005 [cited 2014 Jun 20]. Available from: http://www.publichealthlaw. net/Zoning Fast Food Outlets.pdf

22. Isganaitis E, Lustig RH. Fast food, central nervous system insulin resistance, and obesity. Arteriosclerosis, Thrombosis, and Vascular Biology. 2005. p. 2451-62.

23. Nurwanti E, Hadi $H$, Julia M. Paparan iklan junk food sebagai faktor risiko terjadinya obesitas pada anak sekolah dasar kota dan desa di Daerah Istimewa Yogyakarta. J Giz dan Diet Indones. 2013; 1(2): 59-70.

24. Bowman S, Gortmaker S, Ebbeling C, Pereira $M$, Ludwig D. Effects of fast-food consumption on energy intake and diet quality among children in a national household survey. Pediatrics. 2004;113:112-8.

25. Sanigorski a M, Bell a C, Kremer PJ, Swinburn $B$ a. Lunchbox contents of Australian school children: room for improvement. Eur J Clin Nutr. 2005;59(11):1310-6.

26. Kopelman P. Obesity as a medical problem. Nature. 2000;404:635-43.

27. Arundhana Al, Hadi H, Julia M. Perilaku sedentari sebagai faktor risiko kejadian obesitas pada anak sekolah dasar di Kota Yogyakarta dan Kabupaten Bantul. J Giz dan Diet Indones. 2013; 1(2): 71-80.

28. Janssen I, Leblanc AG. Systematic review of the health benefits of physical activity and fitness in school-aged children and youth. Int J Behav Nutr Phys Act. 2010;7:40.

29. Lowry R, Wechsler H, Galuska D, Fulton J, Kann $\mathrm{L}$. Television viewing and its associations with overweight, sedentary lifestyle, and insufficient consumption of fruit and vegetables among US High school students: differences by race, ethnicity, and gender. J Sch Health. 2002;72(10):413-21.

30. Astiti $D$, Hadi $H$, Julia M. Pola menonton televisi sebagai faktor risiko obesitas pada anak di sekolah dasar Kota Yogyakarta dan Kabupaten Bantul. J Giz dan Diet Indones. 2013; 1(2): 110-9.

31. Knutson KL, Van Cauter E. Associations between sleep loss and increased risk of obesity and diabetes. Annals of the New York Academy of Sciences. 2008. p. 287-304.

32. Collison KS, Zaidi MZ, Subhani SN, Al-Rubeaan $\mathrm{K}$, Shoukri M, Al-Mohanna F a. Sugar-sweetened carbonated beverage consumption correlates with BMI, waist circumference, and poor dietary choices in school children. BMC Public Health. 2010;10:234-46.

33. Cooke LJ, Wardle J. Age and gender differences in children's food preferences. Br J Nutr. 2005;93:741-6.

34. Epstein LH, Paluch R a, Raynor H. Sex differences in obese children and siblings in family-based obesity treatment. Obes Res [Internet]. 2001;9:746-53. Available from: http:// www.ncbi.nlm.nih.gov/pubmed/11743058

35. Apfelbacher CJ, Loerbroks A, Cairns J, Behrendt $\mathrm{H}$, Ring J, Kramer U. Predictors of overweight and obesity in five to seven-year-old children in Germany: results from cross-sectional studies. BMC Public Health. 2008;8:171.

36. Ochiai $H$, Shirasawa $T$, Ohtsu $T$, Nishimura $R$, Morimoto A, Obuchi R, et al. Number of siblings, birth order, and childhood overweight: a population-based cross-sectional study in Japan. BMC Public Health [Internet]. 2012;12(1):766. Available from: BMC Public Health

37. Poti JM, Popkin BM. Trends in Energy Intake among US Children by Eating Location and Food Source, 1977-2006. J Am Diet Assoc. 2011;111(8):1156-64.

38. Appelhans BM, Waring ME, Schneider KL, Pagoto SL, DeBiasse MA, Whited MC, et al. Delay discounting and intake of ready-to-eat and away-from-home foods in overweight and obese women. Appetite. 2012;59(2):576-84. 